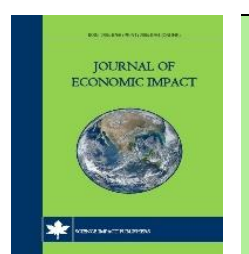

Available Online

Journal of Economic Impact

ISSN: 2664-9764 (Online), 2664-9756 (Print)

http://www.scienceimpactpub.com/jei

\title{
ECONOMIC COST OF EDUCATION AND BEHAVIOR OF PARENTS TOWARDS CHILD LABOR
}

\author{
Mahnaz Muhammad Ali a, Mariam Abbas Soharwardi ${ }^{\text {b,* }}$ \\ ${ }^{a}$ Department of Economics, The Islamia University of Bahawalpur, Bahawalpur, Pakistan
}

\section{ARTICLE INFO}

\section{Article history}

Received: August 15, 2021

Revised: November 23, 2021

Accepted: November 25, 2021

\section{Keywords}

Child labor

Economic cost

Education

\section{ABSTRACT}

This research was aimed to check the relationship between the economic cost of education and the behaviour of parents towards child labour. Primary data was used to investigate the impact of the economic cost of education on parents' behaviour towards child labour. One hundred and fifty selected parents were interviewed through a structured questionnaire. Seventy five parents were selected from the group who did not want to send their children to work, and seventy five parents were selected from the group who wanted to send their children to work for comparative analysis. Binary Logistic Regression model was used for empirical findings. The results showed a strong positive relationship between the economic cost of education and the behaviour of parents towards child labour. So it is concluded that the economic cost of education can be one of the main determinants of favourable behaviour of parents towards child labour. As a policy suggestion, it is recommended that free quality of education should be provided by the public sector to address the chronic issue of child labour.

\footnotetext{
* Email: mariam.abbas@iub.edu.pk

https://doi.org/10.52223/jei4012202

(C) The Author(s) 2022.

This is an open access article under the CC BY license (http://creativecommons.org/licenses/by/4.0/).
}

\section{INTRODUCTION}

Child labor is a persistent global issue, and it is an immense challenge for the world in general and for developing and less developed countries specifically. The term child labor can be defined as "any work that can be harmful for children morally, socially, physically, and mentally". Moreover, any work that can deprive children of their childhood, their potential and dignity is considered as child labour (ILO, 2020). Like the other world, child labor is a big issue for developing nations like Pakistan. Child labor is a hazard not only on humanitarian grounds but is also injurious socially and economically. Socially it can cause social unrest and economic outcomes of child labor in the form of health and education can hamper the quality and quantity of human capital (Kyambalesa, 2019). Developing countries mostly have large labor force with low economic growth rates. These countries can utilize this labor force to enhance the growth rate of their countries. The quality of this labor force is highly dependent on education and skills of this workforce (Ahmed, 2019). However, if the parents as a rational economic actor prefer work on education and send their children to work instead to get them enrolled in school, then this micro level decision can accelerate the poverty at a macro level by hampering the future productivity of children in total output level (Glewwe, 2002).

A study on Cameroon was conducted by Bikoue (2021) on the determinants of child labor. This study also used micro data of Cameroon household survey and carried out estimation using a bivariate probit model. The results of the analysis revealed that if a child was out of school then there would be more chances of work. If the father or both parents of the child were dead, or they are uneducated, having low income level, or, head of the family worked in agriculture sector, or living in rural area, all these factors encourage child labor. The high cost of education can cause more child labor. Free education can help to reduce child labor. China has introduced a free compulsory education in rural China. Tang et al. (2019) tried to evaluate the impact of this educational reform on the incidence of child labor in china. A survey data from China Family Panel Studies (CFPS) is used for the analysis. The results of the analysis showed that free education can reduce child labor for boys and the reform had no significant impact on child labor of girls. One additional semester of free education can reduce child labor in boys by $8.3 \%$. Further, this educational reform has more impact on families having low socio-economic status. The results of the analysis also concluded that the reform can enlarge the educational gap between girls and boys because parents redistributed their transfers from girls to boys.

Although there are many important determinants of child labour but Mbebi (2018) focused on area of residency and gender as core determinants of child labor in Cameroon by using micro data from the third survey of Cameroon Household Survey (CHS) study and used descriptive analysis 
and multinomial logit model for analysis. Results of the empirical investigation showed that area of residency played an important role in child labor. Increased income level in rural area has a negative effect on child labor while it has no effect in urban area of residency. The second outcome showed that land ownership of such land which require labor work, can increase the child labor in both urban and rural area and endorsed the wealth paradox.

In Pakistan there are different forms of child labor. A study conducted by Latif et al. (2016) identified the socio-economic and political determinants of child labor engaged on brick kilns in district Jhang. The research design used in the study was qualitative and in-depth interviews were used as a tool for data collection. Thirty respondents were interviewed using purposive sampling. The results of the data analysis showed that lack of education, the need for more money by families and poor implementation of child labor laws by the government were responsible factors for child labour at brick kilns. Another study by Zafar et al. (2016) was conducted to identify child labor's socio-economic and political factors in Pakistan. The study was based on the quantitative and qualitative research design. Some data was collected through structured interviews, and some were collected using in-depth interviews. Descriptive analysis was used to make conclusions. Respondent's education level was primary determinant of child labor, indicating high dropout rate at secondary level. Family type was an important determinant indicating that extended family or single parent family was more inclined to child labor. Study found poverty, income level and unemployment of youth as economic determinants of child labor. Family size, family type, culture, mistrust on education system and rural-urban migration as social determinants and failure of Government to provide free education, weak implementation of child labor laws and lack of interest of political leaders in this issue as political determinants of child labor in Pakistan.

Another argument about the choice of number of children and their education is longevity argument. Hazan and Zoabi (2006) claimed that more longevity of children could increase the quantity and quality of children. The study concluded that as longevity (life expectancy) increases, parents make decision to have more upspring because due to longevity their investment on children gave them greater returns. These increasing returns contributed towards human capital accumulation that eventually uplifts the economic growth of a country, they claimed. Parent's attitudes towards unsprings can play an important role in child labor. Sakamoto (2006) conducted a study to highlight the determinants of child labor in rural India. Using household data, he found that household poverty, low educational attainments of parents and lack of schools were the main determinants. Along with these determinants using probit model study also explored that parents' behavior towards their children was also a prominent determinant of child labor. If parents were more concerned with their child development then there was less incidence of child labor. Moreover, if father has greater power in household's decisions then children are more likely involved in child labor.

Chimombo (2005) conducted case studies to dig out the factors responsible for child labor. The research collected the data of Malawi schools for five years using observations, focused group discussion and interviews parents, teachers, students and policymakers. Based on this qualitative approach it was concluded that high opportunity cost of schooling significantly related to the decision of child labor. Higher the economic cost more incidence of child labour prevailed. It is general presumption that poor households are more inclined towards child labor. But this is not true in all situations. Bhalotra and Heady (2003) tested the wealth paradox for the two economies, Pakistan and Ghana. Primary survey data was used to test the paradox. It was hypothesized that in agrarian areas children of rich families are more likely in work than the children of poor families. After empirical investigation, it was concluded that the wealth paradox exists partially. Girls were more likely to work in land rich families. However, this paradox did not hold in case of boys after controlling the other relevant variables. The study explained the reason for the paradoxical situation is labor market imperfections and credit market failure.

Literature suggested that there can be different reasons for the favorable behavior of parents towards child labor. A study conducted by Chandra (2000) collected the primary data of three districts in India, Govandi, Ganeshwadi and Baignwadi to determine the factors contributing towards encouraging behavior towards child labor. Quantitative and qualitative tools for data collection were used to get the data of slums areas of the chosen districts. Semi-structured interviews, indepth discussions with the respondents and case studies were used to collect the insight information of the phenomenon. Findings of the empirical investigation of the data collected by 25 selected parents revealed that decision of child labour mainly depend on the family background and economic status of the family.

High opportunity for education significantly determines the level of a child's hours of work. Ranjan (2001) conducted a comparative study for Pakistan and Peruvian to analyze the role of opportunity cost in child labor decision of household. It was hypothesized that more work by child can reduce poverty and more schooling hours of child can increase poverty. Both the hypothesis came true for Pakistan data and it was proved that child labour could reduce household poverty while hours of schooling can increase poverty. But none of the hypotheses was true for Peruvians. Further data sets of both countries proved that adult's education could increase the welfare of the child. Another study explored the same role of the opportunity cost of education in child labor.

Buchmann (2000) explored another aspect of decision of schooling and child labour. The primary data of Keyna was used for investigation. Data from 596 households was collected by the data collection team. It was hypothesized that if parents expected high future financial help from upspring then they were decided to send their child to school. Secondly, decision about girl's education was highly correlated with the gender base wage discrimination of labour market. The results of the research endorsed the hypothesized relationship. Boys' school enrolment was significantly positively related with the future financial returns to education and girls' school enrolment was hampered due to low wage rate for female in labour market. A similar argument was claimed by Evans 
(2000) that gender disparity existed in school enrolment. A study based on primary data was conducted in Tanzania to check the determinants of boys' and girls'. Semi structured interviews and focus group discussions were used to explore the phenomenon. It was identified that girls had high opportunity cost of schooling than boys. Only school fee (explicit cost) was not the impediment of girls' schooling but they had to perform a duty as caretaker for old persons, ill adults and younger siblings. Due to their role in domestic chores had emerged as a big hindrance for girls' school enrolment instead of direct expenses of the school. In comparison, boys had a low opportunity cost to attend school.

\section{Current Situation of Child Labour}

The data on labor estimates shows that one out of every tenth children globally is part of child labour. Total 160 million children, including 63 million girls and 97 million boys, fashioned child labour. About $60 \%$ of the total world child labor exists in Asia. The statistics show that child labour is more prevalent in boys than girls. A constant combat is continued to eliminate child labour, especially in the developing world. However, the efforts to eradicate child labor have been stagnated since 2016. In addition to this, the current situation of COVID-19 has further dampened the efforts against child labor (UNICEF, 2021).

In Pakistan, 3.3 million children are ensnared by child labor and are deprived of education and their childhood. In Pakistan, $39.2 \%$ population lives below the poverty line (Ali et al., 2021). Due to the extreme circle of poverty, parents cannot send their children to school; they do not have funds to invest in their child's education. Instead they want their children to join the labour market immediately to earing livelihood (Luckstead et al., 2019).

\section{Factors Determining the Child Labor}

There are different social, demographic, economic and cultural factors discussed in available literature as determinants of child labour. Many researchers believe that factors that can cause child labour vary across regions, countries, and continents (Ray, 2009; Bonnet, 1993). Some studies proved poverty is the main cause of poverty (Shafiq, 2007; Lachaud, 2008; Zapata et al., 2011). Bonnet (1993) argued that for African child labour, poor quality of schooling and irrelevant skills of graduates according to labour market encouraged parents to get their child out from school. Afriyie et al. (2019) identified that child age, gender, birth order, mother living, region, and residence location are factors determining child labour behaviour.

\section{Cost of Education and Child Labour}

Whether to invest in a child's education or not is purely a microeconomic decision. Every household individually tradeoff between work and education on the basis of cost-benefit analysis. While choosing schooling, the household considers all the expenditures associated with the education of a child. The total economic cost of a school can be categorized as explicit cost (also called accounting cost) and implicit cost (also called opportunity cost). On the other side benefits of education is associated with the future earnings of the child.
The benefits of education can be different for individuals and society (Bargain \& Boutin, 2021).

Most contemporary researchers in economics are interested in child labor because of the impact of child labor on human capital accumulation. A high level of child labour is usually associated with low literacy rates, which become the main cause of poverty. Poverty leads to a low level of human capital accumulation and affects the economic growth of a country (Dayioglu-Tayfur \& Kirdar, 2020). According to the research by Population Action Investment, 730 million more people will join the world's workforce by 2020 and $90 \%$ of these workers will be from developing nations. For economic development, we have to invest in our human capital, while child labor is the main hurdle in the accumulation of human capital. Keeping in view the sustainable development goals, "Target 8.7 aims to eliminate the worst forms of child labor, including the recruitment and use of child soldiers, as well as to end all forms of child labor by 2025", there is a need to evaluate the phenomenon of child labor and the impact of the cost of schooling on child labor. The current study is conducted to assess the economic cost of education and to find out the relationship between the economic cost of education and parents behaviour towards child labour, which will help the policymakers to address one of the crucial reason of child labor in terms of the economic cost. The specific objective of the study is to explore the impact of the economic cost of education on parent's behaviour towards child labour. The current study hypothesized that higher the economic cost of education more encouraging behavior of parents towards child labor.

\section{THEORETICAL FRAMEWORK}

The theoretical framework depicts the understanding of the relationship between the study variables. The main variables used in the present study are the economic cost of education and the behavior of parents toward child labor.

\section{Economic Cost of Education}

The economic cost is the total cost of education beard in the form of direct expenses and the indirect expenses in the form of income forgone by the child to attend the school. There are two components of the economic cost of education; (i) Direct/Explicit cost of education and (ii) Opportunity/Implicit cost of education.

Direct/Explicit Costs of Education: Direct/explicit cost is outof-pocket expenses born by the student or the student's family, Explicit cost includes; (i) Expense on fee; (ii) Expense on books and uniforms that student or their parents bear, and (iii) Expense on transportation

Implicit Costs/Indirect costs: Earnings by the child that is forgone to pursue the education. The value of the best alternative use of the student's time in work instead of education. Students can earn money or income, which will become very important for their family to fulfil their needs and also basic necessities of life. They can perform the domestic job. They can contribute to family business instead of attending school. Opportunity cost includes; (i) Value of production foregone in family business/farm (Child can contribute in the family business while attending the school) 
and (ii) Earning by the child (If a child does not attend school he can earn money for his family).

\section{Parents Behaviour towards Child Labour}

In this research study, parents' behaviour toward child labour is considered a dependent variable. The parent's behavior about child labor is measured by their decision either to send their child to school or to work. It was hypothesized that low income level, explicit cost and implicit cost of education derive the decision of parents about the schooling of upspring. The theoretical linkages among study variables can be demonstrated in Figure 1.

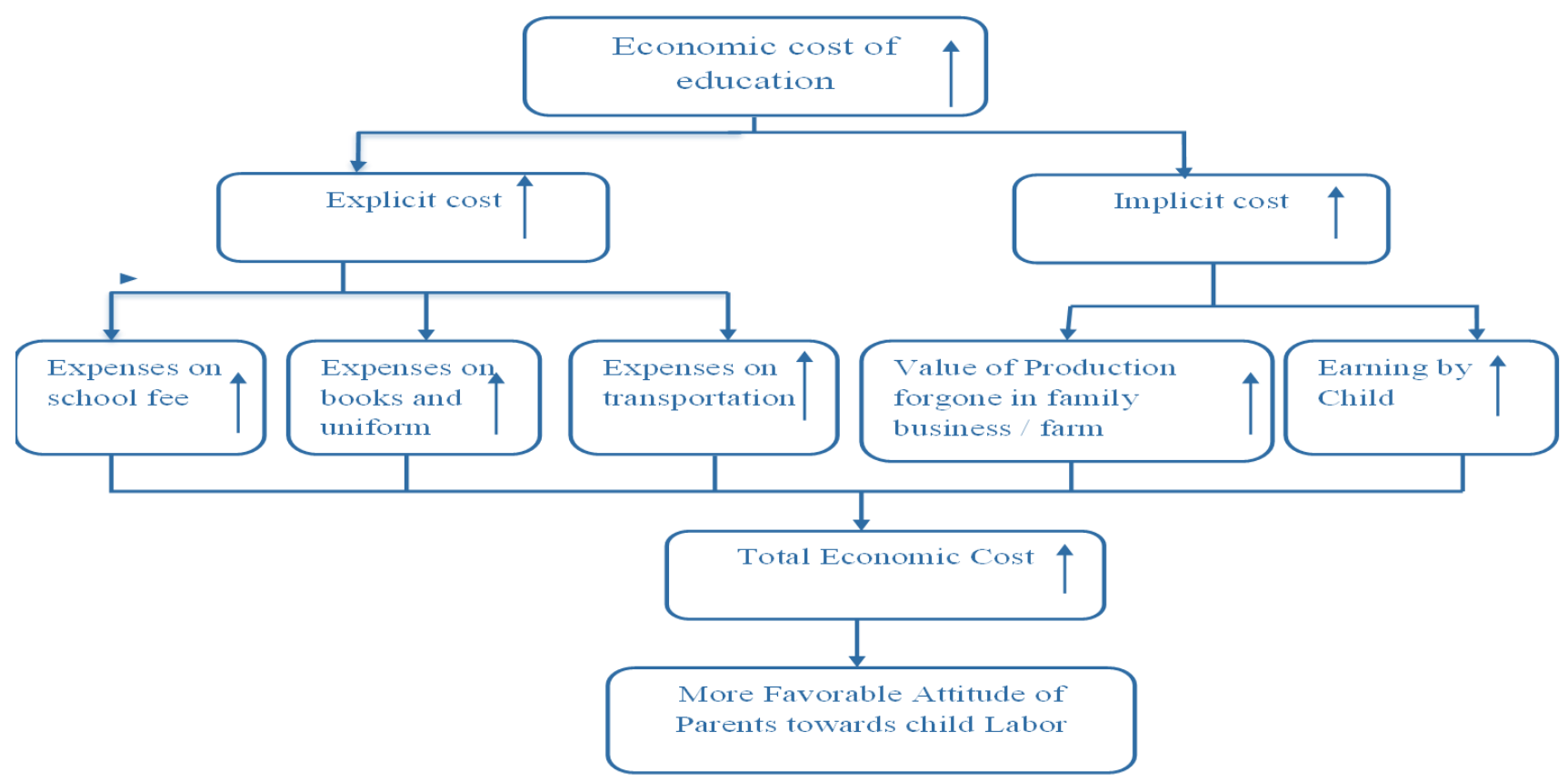

Figure 1. Relationship of economic cost of education and behaviour of parents towards child labour.

\section{METHODOLOGY}

\section{Data Source}

Primary Data is used in this research study and the sample of 150 parents was taken from Chak No. 6 and 7 of the Bahawalpur district. A structured questionnaire is used to collect the data, and a random sampling technique is used to select the households for the interview. The target population is divided into two categories; category 1 and category 2 . Category 1 includes those parents who want to send their children to work. Category 2 includes those parents who don't want to send their children to work. In this study, the researcher has selected 75 those parents who do not want to send their children to work and 75 parents who want to send their children to work.

\section{Model Specification}

In this study model is specified as follows;

Behavior of parents toward child labor $=\mathrm{f}$ (Economic cost of education)

$\mathrm{Y}=\mathrm{f}\left(\mathrm{X}_{1}, \mathrm{X}_{2}, \mathrm{X}_{3}, \mathrm{X}_{4}, \mathrm{X}_{5}, \mathrm{X}_{5}, \mathrm{X}_{6}\right)$

Where $Y_{i}$ denotes the attitude of parents toward child labour, $X_{1}, X_{2}, X_{3}, X_{4}, X_{5}$, and $X_{6}$, are various factors that affect the behaviour of parents toward child labor.

Dependent Variable: Y= Behaviour of parents towards child Labour.

Parents' attitude towards child labor is measured by taking the following categories of parents; parents want to send their children to work=1 and; Parents do not want to send their children to work $=0$.
Independent variables are given as; $\mathrm{X}_{1}=$ Income Level (Measured in Rupees)

$\mathrm{X}_{2}=$ Education Level (Passing Years of Education)

$\mathrm{X}_{3}=$ Number of Family members (Discrete)

$\mathrm{X}_{4}=$ Number of Children (Discrete)

$\mathrm{X}_{5}=$ Implicit Cost

a. Cannot Bear Transport Cost $=1$, Otherwise $=0$

b. School Education is Expensive $=1$, Otherwise $=0$

c. Cannot Purchase books and Uniform $=1$, Otherwise $=0$ $\mathrm{X}_{6}=$ Explicit Cost: The child is not involved in Domestic Business $=1$, Otherwise $=0$.

\section{Binary Logistic Model}

The logistic regression model is used to get the empirical results to solve the behaviour problem, and in the current study, it would be modelling the variations in the probability of the parent's behaviour towards child labour. Proportions and probabilities are different as compared to continuous data in many ways. In this model dependent variable is bounded by 0 and 1 . This means that it cannot assume normality for proportion and would recognize that proportionality has a binomial distribution. Unlike the normal distribution, the mean and variance of the Binomial distribution are not independent. The mean is denoted by $\mathrm{P}$, and the variance is denoted by;

$\mathrm{P}^{*}(1-\mathrm{P}) / \mathrm{n}$

Where $\mathrm{n}$ is the number of observations and $\mathrm{P}$ is the probability of the event occurring (e.g., the probability of parents to send their child for work, or do not send for work) in anyone 'trial' 
(for any one individual in this example). According to the binary set of data, it is assumed that the variable had a mean $\mathrm{P}$ and a variance $\mathrm{P}^{*}(1-\mathrm{P})$, and this variable would have a Bernoulli distribution. When it has a proportion as a response, we use a logistic or logit transformation to link the dependent variable to the set of explanatory variables. The logit link has the form:
$\operatorname{Logit}(\mathrm{P})=\log [\mathrm{P} /(1-\mathrm{P})]$

\section{RESULTS AND DISCUSSION}

By using the method of Binary Logistic Regression, with the help of SPSS, the relationship between the study variables has been checked, as shown in Table 1 .

Table 1. Binary logistic regression (Economic cost and child labour).

\begin{tabular}{|c|c|c|c|c|}
\hline $\begin{array}{l}\text { Dependent } \\
\text { Variable }\end{array}$ & Independent Variables & Coefficient & P value & Odd Ratio \\
\hline \multirow{10}{*}{ 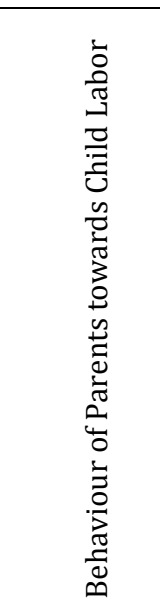 } & Education Level & -.741 & .096 & .477 \\
\hline & Income level & -2.700 & .127 & .067 \\
\hline & Number of children & -3.417 & .021 & .033 \\
\hline & Number of Family Members & 2.949 & .020 & 19.084 \\
\hline & Implicit Cost (No School in Location) & 4.111 & .137 & 61.020 \\
\hline & Implicit Cost (Cannot bear Transportation Expenses) & 2.060 & .065 & 7.845 \\
\hline & Implicit Cost (Education Expensive Item) & 2.205 & .073 & 9.066 \\
\hline & Implicit Cost (Cannot Purchase books and Uniform) & 2.174 & .042 & 8.798 \\
\hline & $\begin{array}{l}\text { Explicit cost(Involvement of child in Domestic } \\
\text { Business) }\end{array}$ & -2.333 & .143 & .097 \\
\hline & Constant & -27.548 & .029 & .000 \\
\hline
\end{tabular}

Note: $P$ Value=Level of significance.

The result showed that education has a significant impact on the attitude of the parent's toward child labor. When parents are educated, then they will prefer their children to go to school instead of becoming part of child labour. On the contrary, uneducated and illiterate parents prefer their children to join the labour market immediately. So there is a negative relationship between the education level of the parents and their attitude towards child labour. The result showed that income has a significant impact on the attitude of parents toward child labor (Evans, 2002). Parents do not want to send their children to work when they earn enough and high income, but when parents' income is low, they send their children to work to meet their needs (Mbebi, 2018). So there is a negative relationship between the income level and attitude of parents toward child labor but insignificant in this study. The result showed that the number of children has a significant impact on parent's attitudes towards child labour (Dayioglu-Tayfur \& Kirdar, 2020). When there is a large number of children, then parents send some child to work and some child to school. So there is a negative relationship between the number of children and parent's attitude towards child labor. The result showed that the number of family members has a significant impact on the attitude of parent's toward child labor. When family has more children then parents send their children to work (Luckstead et al., 2019). So the attitude of parents is positive toward child labor due to large family size. The result showed that no school in location has a significant impact on the attitude of parent's toward child labor. When there is no school in the location, then the attitude of parents toward child labor is also positive (Edwards \& Wenger, 2019), and parents send their children to work. The result showed that transportation expenses for schooling have a significant impact on the attitude of parents towards child labor. Parents have low incomes, and they cannot be able to bear the transportation expenses then they send their children to work instead of sending them to school. The result showed that education is an expensive item and it has a significant impact on parent's attitude towards child labor. The result showed that the purchase of books and uniforms also has a significant impact on parent's attitudes towards child labor. The income of parents is low, and they are not able to purchase books and uniforms (Morgan, 2010). In previous studies, domestic business has a significant impact on the attitude toward child labour (Patunru \& Kusumaningrum, 2013). In the current study relationship between domestic business and child labour showed an insignificant result. When parents are doing their domestic business profitable, and their child is not involved in business, they prefer to send their child to school instead to send him for work. There is a negative relationship between domestic business and child labor (Muller, 2018).

\section{CONCLUSIONS AND RECOMMENDATIONS}

The main objective of this research study was to analyze the relationship between the economic cost of education and behavior of parents toward child labor. For the collection of data the survey technique was used. This study showed that higher economic cost leads to a more favourable attitude of parents towards child labour. It is concluded that there is a strong positive relationship between the economic cost of education and the attitude of parents towards child labor. Child labor is considered as the main constraint and problem in the economic development of a country. It is necessary to 
overcome this problem. Government should take serious steps to resolve this issue. Poverty is considered as the main cause of child labor. Due to poverty, parents send their children to work. So poverty leads to a high economic cost of education, and this high economic cost of education leads to a more favorable attitude of parents towards child labor.

Since the total economic cost of education is high and education becomes an expensive item for poor families. So there is a need to reduce the economic cost of basic education, particularly for poorer families. Government should provide basic education free, which will help to make access of education for everyone. Secondly, Poverty and unemployment of parents are considered as the main reason for parents' favourable behaviour towards child labor. So government should introduce such policies which help to create job opportunities for adults and parents. Thirdly, the poor families have no earning hands, so they send their children to work, and the attitude of parents becomes more favorable toward child labor. So, government should introduce such social security programs for those families who have no earning hand. Fourthly, illiterate people have no awareness of the importance of education. The government should introduce such policies necessary to develop parents' interest and provide awareness for them about the importance of education.

\section{REFERENCES}

Afriyie, L.T., Saeed, B.I.I., Alhassan, A., 2019. Determinants of child labour practices in Ghana. J. Public Health. 27, 211-217.

Ahmed, Q., 2019. The phenomenon of child labor: Causes and spatial trends in 2019 Ramadi City. J. Tikrit Univ. Humanit. 26, 180-201.

Ali, B., Bhatti, S.H., Dayan, F., 2021. Child labour in Pakistan: Way out analyzing constitutional mandate. J. Bus. Soc. Rev. Emerg. Econ. 7, 201-208.

Bargain, O., Boutin, D., 2021. Minimum age regulation and child labor: New evidence from Brazil. World Bank Econ. Rev. 35, 234-260.

Bhalotra, S., Heady, C., 2003. Child farm labor: The wealth paradox. World Bank Econ. Rev. 17, 197-227.

Bikoue, S.M., 2021. Determinants of child labour in Cameroon: A bivariate probit model analysis. Asian J. Econ. Model. 9, 105-121.

Bonnet, M., 1993. Child labour in Africa. Int'l Lab. Rev. 132, 371.

Buchmann, C., 2000. Family structure, parental perceptions, and child labor in Kenya: What factors determine who is enrolled in school? Soc. forces 78, 1349-1378.

Chandra, P., 2000. Child labour: Perception of the parents. International Institute for Population Sciences. P.14. Mumbai, India.

Chimombo, J.P.G., 2005. Quantity versus quality in education: Case studies in Malawi. Int. Rev. Educ. 51, 155-172.

Dayioglu-Tayfur, M., Kırdar, M., 2020. Keeping kids in school and out of work: Compulsory schooling and child labor in Turkey. Institute of Labor Economics (IZA). IZA DP No. 13276. Bonn.
Edwards, K.A., Wenger, J.B., 2019. Parents with an unemployed adult child: Labor supply, consumption, and savings effects. IZA J. Labor Econ. 8, 20190001.

Evans, R., 2002. Poverty, HIV, and barriers to education: Street children's experiences in Tanzania. Gend. Dev. $10,51-62$.

Glewwe, P., Koch, S., Nguyen, B.L., 2002. Child nutrition, economic growth, and the provision of health care services in Vietnam in the 1990s. The World Bank. https://doi.org/10.1596/1813-9450-2776.

Hazan, M., Zoabi, H., 2006. Does longevity cause growth? A theoretical critique. J. Econ. Growth 11, 363-376.

ILO, 2020. Child labour: Global estimates 2020, Trends and the road forward. 2020. Available online (accessed on 20

2021):https://www.ilo.org/wcmsp5/groups/public/--ed_norm/--ipec/documents/publication/wcms_797515.pdf.

Kyambalesa, H. 2019. Child labor: Causes, effects and deterrents. Effects and deterrents, Ssrn Electronic Journal. https://doi.org/10.2139/ssrn.3477641.

Lachaud, J.-P., 2008. Le travail des enfants et la pauvreté en Afrique: un réexamen appliqué au Burkina Faso. Econ. Previs. 47-65.

Latif, A., Ali, S., Awan, A., Kataria, J.R., 2020. Socio-economic and political determinants of child labor at brick kilns: A case study of district Jhang. South Asian Stud. 31, 161 $-174$.

Luckstead, J., Tsiboe, F., Nalley, L.L., 2019. Estimating the economic incentives necessary for eliminating child labor in Ghanaian cocoa production. PLoS One 14, e0217230.

Mbebi, O.E., 2018. Determinants of child labor in Cameroon: The role of area of residence and gender. Rev. deconomie du Dev. 26, 5-52.

Morgan, S., 2010. Credit and child labor: The impact of parents' access to credit on children's labor (Doctoral dissertation). Available online. Retrieved from: https://repository.library.georgetown.edu/handle/10 $822 / 555927$.

Muller, C., 2018. Parent involvement and academic achievement: An analysis of family resources available to the child, in: Parents, Their Children, and Schools. Routledge, pp. 77-114.

Patunru, A.A., Kusumaningrum, S., 2013. Child domestic workers (CDW) in Indonesia: Case study of Jakarta and Greater Areas. International Labour Organization in collaboration with Pusat Kajian Perlindungan Anak, 2013.

Ranjan, P., 2001. Credit constraints and the phenomenon of child labor. J. Dev. Econ. 64, 81-102.

Ray, R., 2009. Education and child labor: A global perspective. World Child Labor An Hist. Reg. Surv. 118-126.

Sakamoto, S., 2006. Parental attitudes toward children and child labor: Evidence from rural India. Institute of Economic Research, Hitotsubashi University. Discussion Paper, 05-136. 
Shafiq, M.N., 2007. Household schooling and child labor decisions in rural Bangladesh. J. Asian Econ. 18, 946966.

Tang, C., Zhao, L., Zhao, Z., 2019. Free education helps combat child labor? The effect of a free compulsory education reform in rural China. Institute of Labor Economics (IZA). 12374.

UNICEF, 2021. UNICEF Annual report 2020, Responding to COVID-19. Accessed online on June 2021 from:
https://www.unicef.org/media/100946/file/UNICEF \%20Annual\%20Report\%202020.pdf.

Zafar, Z., Sarwar, I., Haider, S.I., 2016. Socio-economic and political causes of child labor: The case of Pakistan. Glob. Econ. Rev. 1, 32-43.

Zapata, D., Contreras, D., Kruger, D., 2011. Child labor and schooling in Bolivia: who's falling behind? The roles of domestic work, gender, and ethnicity. World Dev. 39, 588-599.

Publisher's note: Science Impact Publishers remain neutral with regard to jurisdictional claims in published maps and institutional affiliations.

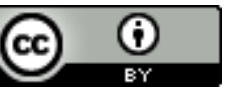

Open Access This article is licensed under a Creative Commons Attribution 4.0 International License, which permits use, sharing, adaptation, distribution and reproduction in any medium or format, as long as you give appropriate credit to the original author(s) and the source, provide a link to the Creative Commons license and indicate if changes were made. The images or other third-party material in this article are included in the article's Creative Commons license, unless indicated otherwise in a credit line to the material. If material is not included in the article's Creative Commons license and your intended use is not permitted by statutory regulation or exceeds the permitted use, you will need to obtain permission directly from the copyright holder. To view a copy of this license, visit https://creativecommons.org/licenses/by/4.0/. 